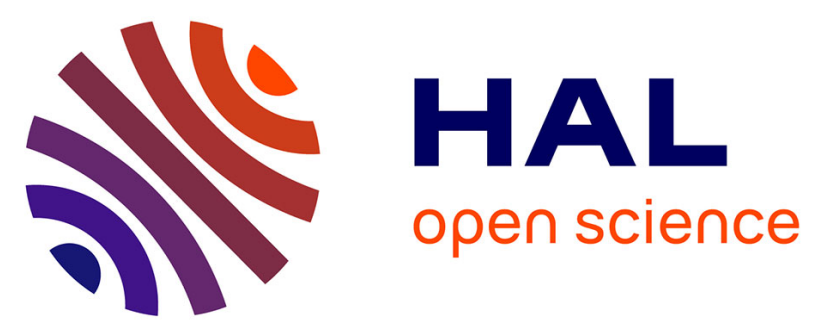

\title{
GENETIC EVIDENCE FOR THE PRESENCE OF TWO DISTINCT HANTAVIRUSES ASSOCIATED WITH APODEMUS MICE IN CROATIA AND ANALYSIS OF LOCAL STRAINS
}

Angelina Plyusnina, Lidija Cvetko Krajinović, Josip Margaletic, Jukka Niemimaa, Kirill Nemirov, Åke Lundkvist, Alemka Marcotić, Marica Miletić Medved, Tatjana Avšič-Županc, Heikki Henttonen, et al.

\section{- To cite this version:}

Angelina Plyusnina, Lidija Cvetko Krajinović, Josip Margaletic, Jukka Niemimaa, Kirill Nemirov, et al.. GENETIC EVIDENCE FOR THE PRESENCE OF TWO DISTINCT HANTAVIRUSES ASSOCIATED WITH APODEMUS MICE IN CROATIA AND ANALYSIS OF LOCAL STRAINS. Journal of Medical Virology, 2010, 83 (1), pp.108. 10.1002/jmv.21929 . hal-00599791

\author{
HAL Id: hal-00599791 \\ https://hal.science/hal-00599791
}

Submitted on 11 Jun 2011

HAL is a multi-disciplinary open access archive for the deposit and dissemination of scientific research documents, whether they are published or not. The documents may come from teaching and research institutions in France or abroad, or from public or private research centers.
L'archive ouverte pluridisciplinaire HAL, est destinée au dépôt et à la diffusion de documents scientifiques de niveau recherche, publiés ou non, émanant des établissements d'enseignement et de recherche français ou étrangers, des laboratoires publics ou privés. 


\section{GENETIC EVIDENCE FOR THE PRESENCE OF TWO DISTINCT HANTAVIRUSES ASSOCIATED WITH APODEMUS MICE IN CROATIA AND ANALYSIS OF LOCAL STRAINS}

\begin{tabular}{|c|c|}
\hline Journal: & Journal of Medical Virology \\
\hline Manuscript ID: & JMV-10-1909.R1 \\
\hline Wiley - Manuscript type: & Research Article \\
\hline $\begin{array}{r}\text { Date Submitted by the } \\
\text { Author: }\end{array}$ & 21-Jul-2010 \\
\hline Complete List of Authors: & $\begin{array}{l}\text { Plyusnina, Angelina; Haartman Inst, University of Helsinki, Dept } \\
\text { Virology } \\
\text { Cvetko Krajinović, Lidija; University Hospital for Infectious Diseases } \\
\text { Margaletic, Josip; Faculty of Forestry, University of Zagreb } \\
\text { Niemimaa, Jukka; Finnish Forest Research Institute, Vantaa } \\
\text { Research Unit } \\
\text { Nemirov, Kirill; Swedish Institute for Infectious Disease Control } \\
\text { Lundkvist, Ake; Swedish Institute for Infectious Disease Control } \\
\text { Marcotić, Alemka; University Hospital for Infectious Diseases } \\
\text { Miletić Medved, Marica; Public Health Institute Brodsko-posavska } \\
\text { County } \\
\text { Avšič-Županc, Tatjana; Medical School, University of Ljubljana } \\
\text { Henttonen, Heikki; Finnish Forest Research Instiute, Vantaa } \\
\text { Research Unit } \\
\text { Plyusnin, Alexander; Haartman Inst, University of Helsinki, Virology }\end{array}$ \\
\hline Keywords: & HFRS , hantavirus, Dobrava virus, Saaremaa virus \\
\hline
\end{tabular}

\section{SCHOLARONE ${ }^{\text {m }}$ Manuscripts}




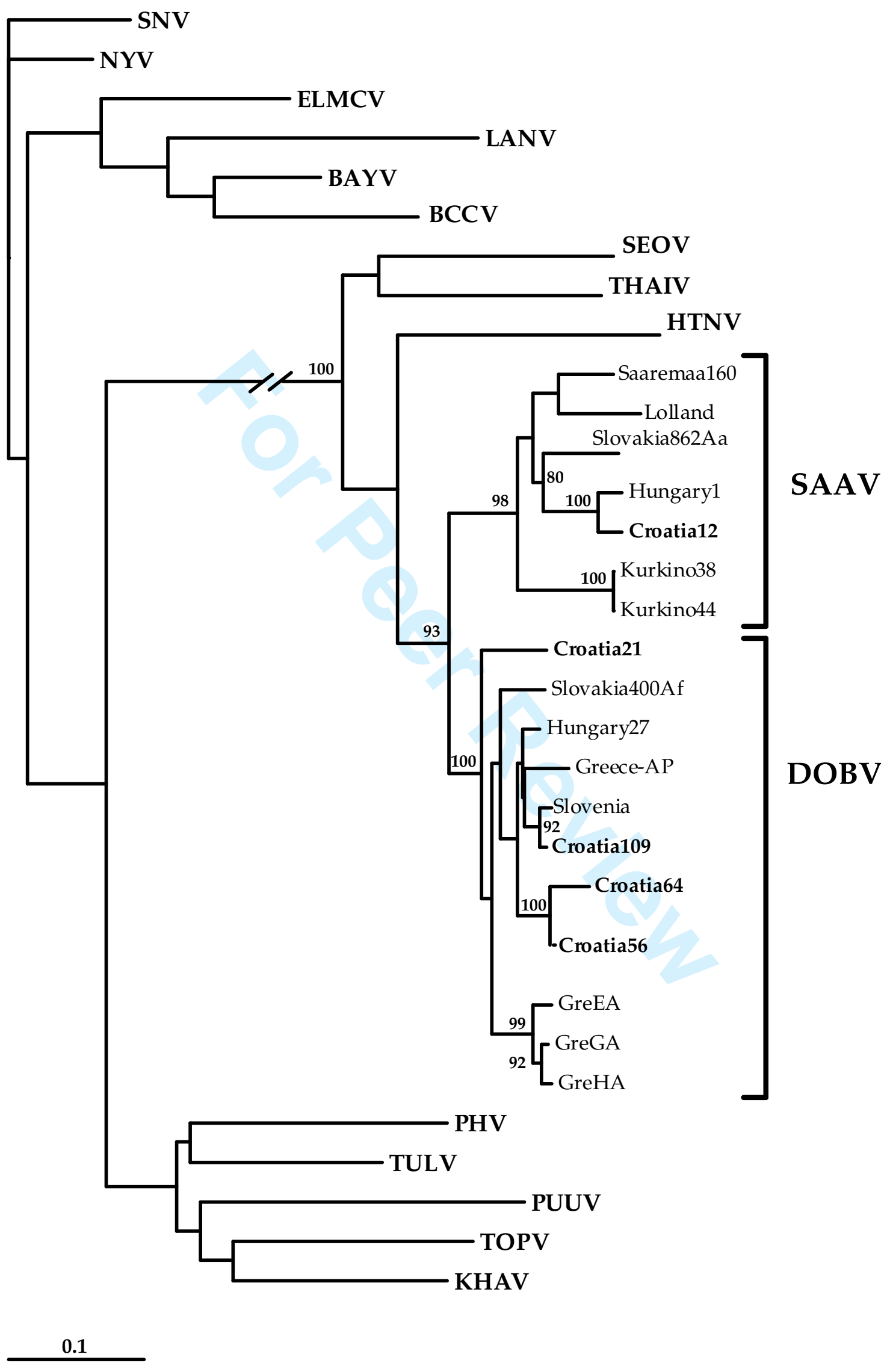


SNV

TULV

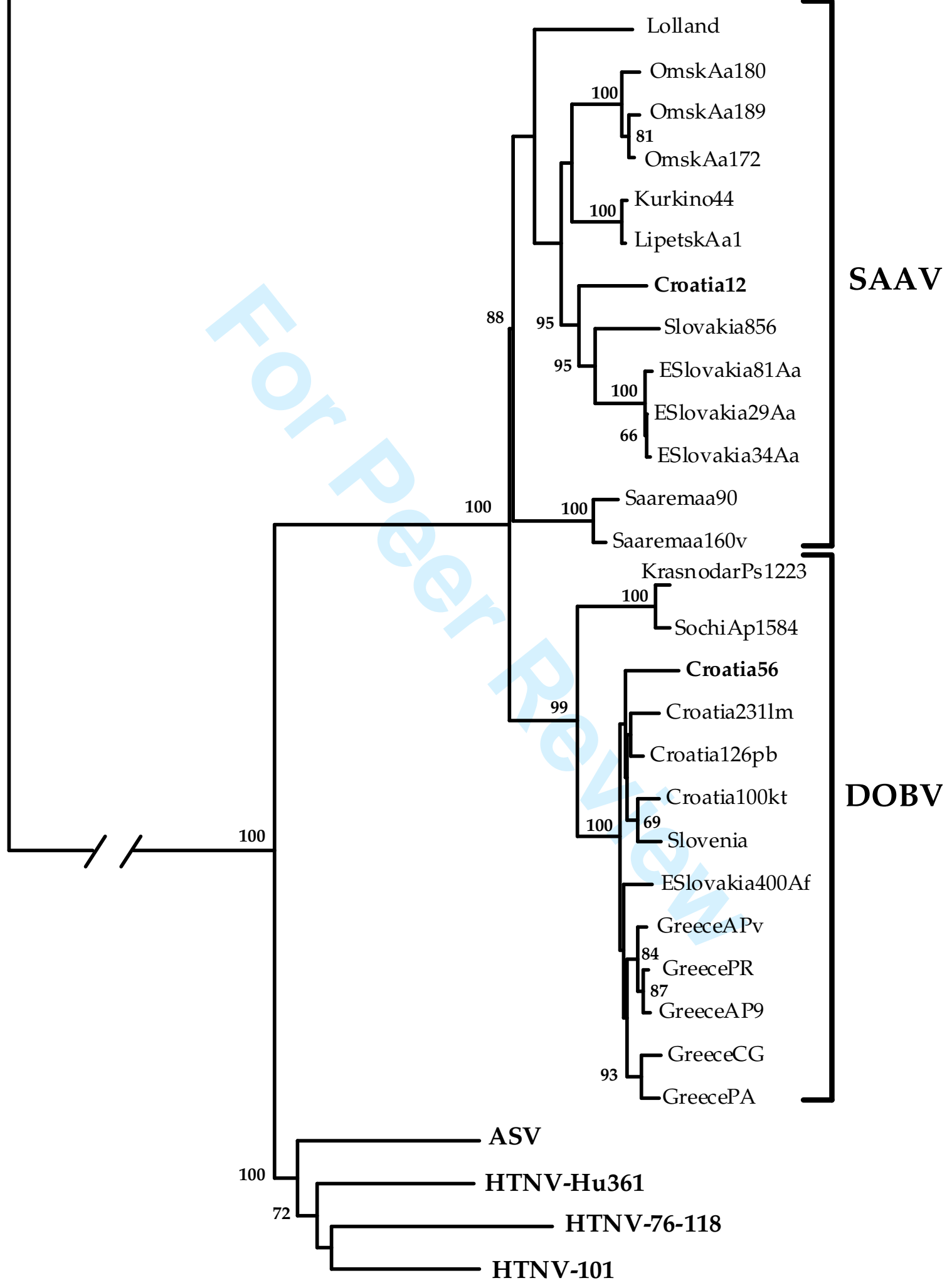

0.1 
For J.Med.Virol.

\section{GENETIC EVIDENCE FOR THE PRESENCE OF TWO DISTINCT}

\section{HANTAVIRUSES ASSOCIATED WITH APODEMUS MICE IN CROATIA AND}

\section{ANALYSIS OF LOCAL STRAINS}

(Short title: Dobrava and Saaremaa hantaviruses in Croatia)

Angelina Plyusnina ${ }^{1}$, Lidija Cvetko Krajinovic ${ }^{2}$, Josip Margaletic ${ }^{3}$, Jukka Niemimaa ${ }^{4}$, Kirill Nemirov ${ }^{5}$, Åke Lundkvist ${ }^{5}$, Alemka Markotic ${ }^{2}$, Marica Miletic Medved ${ }^{6}$, Tatjana Avšic Županc ${ }^{7}$, Heikki Henttonen ${ }^{4}$, and Alexander Plyusnin ${ }^{1 *}$

${ }^{1}$ Department of Virology, Infection Biology Research Program, Haartman Institute, University of Helsinki, Finland

${ }^{2}$ University Hospital for Infectious Diseases, Zagreb, Croatia

${ }^{3}$ Faculty of Forestry, University of Zagreb, Zagreb, Croatia

${ }^{4}$ Finnish Forest Research Institute, Vantaa Research Unit, Vantaa, Finland

${ }^{5}$ Swedish Institute for Infectious Disease Control, Stockholm, Sweden

${ }^{6}$ Public Health Institute Brodsko-posavska County, Slavonski Brod, Croatia

${ }^{7}$ Medical School, University of Ljubljana, Ljubljana, Slovenia 
For J.Med.Virol.

In Europe, Dobrava-Belgrade (DOBV), Saaremaa (SAAV) and Puumala (PUUV) viruses are known to cause hemorrhagic fever with renal syndrome (HFRS). All three hantaviruses are now found in Croatia. Lung tissue samples of 315 Apodemus mice trapped in 2003-2004 were screened for the presence of hantaviral N-Ag and 20 mice $(6.3 \%)$ were found either strongly positive or weak/suspected-positive. Partial sequences of hantavirus $\mathrm{M}$ and S segments were recovered by RT-PCR from six mice and subjected to (phylo)genetic analysis that revealed the presence of four novel strains of DOBV and one of SAAV. Curiously, one of the newly described DOBV strains was found in A. agrarius mouse, i.e. not in the traditional host, A. flavicollis mice, suggesting a spillover event. S segment sequences recovered previously from HFRS cases (Markotic et al., 2002) were confirmed as DOBV sequences; one of which appeared particularly close to the prototype Slovenian DOBV isolate. Taken together with earlier data on PUUV in Croatia, these results show a co-circulation of three European hantavirus pathogens in this country. So far, not a single SAAV sequence has been recovered from HFRS patients either in Croatia or neighbouring Slovenia and Hungary nor in Slovakia suggesting a somewhat lower fequency of acute SAAV infection in humans in this part of Europe than for example in the Baltics.

Key words: HFRS; hantavirus; Dobrava virus, Saaremaa virus. 
For J.Med.Virol.

\section{INTRODUCTION}

Hantaviruses constitute the Hantavirus genus in the family Bunyaviridae [Nichol et al., 2005]. They are enveloped viruses with tri-segmented RNA genome of negative polarity. Small (S), Medium (M) and Large (L) RNA segments encode, respectively, nucleocapsid (N) protein, a precursor for two surface glycoproteins Gn and Gc, and the RNA-dependent RNA polymerase (L protein). In some hantaviruses, the S segment encodes also the nonstructural protein NSs. The function(s) of this protein in the virus replication cycle remain to be determined but there is an evidence that it can counteract an interferon response [Jääskeläinen et al., 2007]. In nature, hantaviruses are maintained in rodents or insectivores infected persistently. When transmitted to humans, usually via aerosolized excreta, some rodent-borne hantaviruses can cause disease. In Europe, Dobrava-Belgrade (DOBV), Saaremaa (SAAV) and Puumala (PUUV) viruses cause hemorrhagic fever with renal syndrome (HFRS) of varying severity. In Asia, the main causative agents of HFRS are Hantaan and Seoul (SEOV) viruses. In the Americas, Sin Nombre, Andes and related viruses are associated with hantavirus (cardio)pulmonary syndrome (HCPS) [for a reviews, see Vapalahti et al., 2003; Schmaljohn and Hjelle, 1997]. Very little is known about hantaviruses in Africa [Klempa et al., 2006, 2007] and nothing is known about these viruses in Australia.

DOBV, SAAV, PUUV, and SEOV are found in Europe, often in co-circulation, and the first three viruses also in association with human HFRS cases [Vapalahti et al., 2003]. DOBV, harbored by yellow-necked mice (Apodemus flavicollis), is associated with severe HFRS mostly in the Balkans and Alpe-Adrian region [Papa et 
For J.Med.Virol.

al., 1998; Avšic Županc et al., 1999; Markotic et al., 2002; Jakab et al., 2007]. The natural host for SAAV is the striped field mouse (Apodemus agrarius); the virus causes mild HFRS in the Baltics, Central Europe and the European part of Russia [Lundkvist et al., 1998; Plyusnin et al., 1999; Golovljova et al., 2000; Sibold et al., 2001; Klempa et al., 2004, 2008]. It should be noted that SAAV was considered initially a genetic variant of DOBV carried by A. agrarius [Plyusnin et al., 1997; Nemirov et al., 1999] and for a while there was a controversy in the taxonomy and terminology of SAAV. The virus is now recognized as a distinct species [for the latest taxonomy, see www.ictvonline.org] but, in some publications, it is still named "DOBV-Aa".

PUUV is carried by bank voles (Myodes glareolus) and causes HFRS, usualy mild, in Northern and Central Europe, the Baltics, European part of Russia and Alpe-Adria [Settergren et al., 1989, Mustonen et al., 1994; Tkachenko et al., 1998; Golovljova et al., 2000, 2007; Heyman et al., 2001; Markotic et al., 2002; Cvetko et al., 2005; Avšic-Županc et al., 2007; Hoffmann et al., 2008].

The whole of Croatia except costal region and islands is endemic for HFRS. Serological and genetic findings in HFRS patients provided evidence that PUUV and Dobrava virus (DOBV) have been two major pathogenic hantaviruses circulating in Croatia and causing hantavirus infections in humans [Markotic et al. 2002, Cvetko et al., 2005]. Apathogenic Tula virus was detected in wild rodents in Croatia as well [Scharninghausen et al., 2002]. Croatia borders Slovenia to the northwest and has an extended border with Bosnia and Herzegovina, one of the largest HFRS regions in Europe [Markotic et al., 1995; Hukic et al., 2009]. Nowhere else is the co-existence of PUUV and DOBV as obvious as in Croatia, Bosnia and Herzegovina and Slovenia 
For J.Med.Virol.

96 [Markotic et al., 2002; Cvetko et al., 2007; Lundkvist et al., 1997; Avšic et al., 1999].

97 During the HFRS outbreak in Croatia in 2002 when more than 400 patients were 98 serologically confirmed as HFRS positive, PUUV was shown to be dominant 99 pathogen [Miletic-Medved et al. 2002; Kuzman et al. 2003].

100 Phylogenetic analysis of wild-type (wt) PUUV strains from the 2002-outbreak 101 area showed that they clustered together with the strains from Slovenia and Austria 102 forming distinct Alpe-Adrian genetic lineage [Cvetko et al., 2005]. Most recently, 103 Hungarian PUUV strains were added to this lineage [Plyusnina et al., 2009].

104 The knowledge on DOBV and SAAV genetic variants in Croatia is still 105 restricted to partial S segment sequences recovered from three HFRS patients 106 [Markotic et al., 2002]. To fill this gap, we attempted to recover and analyze DOBV 107 and SAAV sequences from carrier rodents, Apodenus mice, trapped during field 108 expeditions organized by the Faculty of Forestry, University of Zagreb and the 109 Finnish Forest Research Institute. 
For J.Med.Virol.

111

112

113

114

115

116

117

118

119

120

121

122

123

124

125

126

127

128

129

130

131

132

133

134

\section{MATERIALS AND METHODS}

Trapping of rodents. Rodents were collected during two expeditions, in northeast Croatia in May 2003 and the south-west parts of Croatia in September, 2004 at the following locations: Migalovci, Merolino, Loze, Nova Gradiška, Gratac/Mala Kapela, and Delnice/Mala Kapela. Animals were trapped with snap traps, set in the evening and checked early in the morning. Animals were placed in cooler box in the field and kept subsequently in a refrigerator until dissected on the same day. Lung tissue samples were taken from all animals and preserved in RNAlater reagent (Ambion, Applied Biosystems, Carlsbad, CA, USA) for genetic analyses. Also blood and serum samples were taken for further serological/epidemiological analyses by pressing the heart on filter paper.

Screening of rodent samples. Lung tissue samples were screened first for hantavirus nucleocapsid $(\mathrm{N})$ protein antigen $(\mathrm{N}-\mathrm{Ag})$ by immuno(Western)blotting (WB) as described earlier [Plyusnin et al., 1995]. In brief, approximately $100 \mathrm{mg}$ of tissue was placed into 400-500 $\mu$ l of Laemmli sample buffer and homogenized by sonication. Aliquots of $10 \mu \mathrm{l}$ were separated by electrophoresis in $10 \%$ sodium dodecyl sulphate-polyacrylamide gels and then immunoblotted with rabbit polyclonal antibody raised against DOBV. Swine anti-rabbit antibodies conjugated with the horse radish peroxidase (Dako, Glostrup, Denmark) were used as secondary antibodies.

\section{Reverse transcription - polymerase chain reaction (RT-PCR) and sequencing.} RNA was extracted from lung tissue samples using the Tripure reagent (Boehringer Mannheim) following recommendations of the manufacturer. RNA was then 
For J.Med.Virol.

135 subjected to RT-PCR to recover partial M segment and S segment sequences, 136 (sequences of primers and other experimental details are available upon request). 137 PCR amplicons were gel-purified with QIAquick Gel Extraction -kit (QIAGEN, $138 \mathrm{GmbH}$, Germany) and sequenced directly using ABI PRISMTM Dye Terminator 139 sequencing kit (Perkin Elmer/ABI, NJ). SAAV and DOBV genome sequences 140 described in this paper have been deposited to the GenBank sequences database 141 under accession numbers FN813291-7.

142 Mitochondrial DNA (mtDNA) analysis was performed as described earlier 143 [Nemirov et al., 2002]. The analysis was done to confirm the species status, 144 particularly that of $A$. flavicollis and $A$. sylvaticus that sometimes are problematic to 145 identify. Briefly, DNA was extracted from lung tissue samples using the Tripure 146 reagent (Behringer Mannheim). A 427 nt-long PCR-product from the D-loop147 encoding region was amplified with primers 5'-CCACCATCAGCACCCAAAGCTG148 3' and 5'-CTGAAGTAAGAACCAGATGTCTG-3'. The product was purified from the 149 gel and subjected to direct sequencing. For comparison, mtDNA sequences of $A$. 150 agrarius, $A$. flavicollis and $A$. sylvaticus were retrieved from the GenBank nucleotide 151 databases.

Phylogenetic analysis. Multiple nucleotide sequence alignments were prepared 153 manually using the SeqApp 1.9a169 sequence editing program. Phylogenetic analysis 154 was performed using the PHYLIP program package [Felsenstein, 1993]. 500 155 bootstrap replicates were generated using the "Seqboot" program and submitted to 156 the distance matrice algorithm ("Dnadist" program), with the maximum likelihood 157 model for nucleotide substitutions). The resulting distance matrices were analysed 158 with either Neighbor-Joining (NJ) or Fitch-Margoliash (FM) tree-fitting algorithms 
For J.Med.Virol.

159 ("Neighbor" and "Fitch" programs, respectively). The bootstrap support values were

160 calculated with the "Consense" program. Hantavirus sequences used for comparison 161 were recovered from the GenBank.

162 
For J.Med.Virol.

163

164

165

166

167

168

169

170

171

172

173

174

175

176

177

178

179

180

181

182

183

184

185

186

\section{RESULTS}

Screening of rodents. In May, 2003, 362 rodents were trapped. Of those, 252 were Apodemus mice. In the field, 18 animals were classified preliminarily as $A$. agrarius, 66 as $A$. flavicollis and 151 as $A$. sylvaticus. Of 245 small mammals trapped in September 2004, 80 were classified as Apodemus mice. These included 75 yellownecked mice (A. flavicollis) and five wood mice (A. sylvaticus). All 332 Apodemus mice were subjected to the WB-screening for hantaviral $\mathrm{N}-\mathrm{Ag}$ and 20 mice $(6.3 \%)$ were found either strongly positive or weak/suspected-positive. These mice, two $A$. agrarius, six A. flavicollis, and 12 A. sylvaticus, were trapped at four localities: Migalovci, Nova Gradiška, Loze and Mala Kapela. Lung tissue samples of these mice were further tested for the presence of SAAV/DOBV genome by RT-PCR designed to amplify partial M segment sequence, nucleotides (nt) 1673 to 1989. Six samples, two from A. agrarius and four from A. flavicollis were positive.

Genetic analysis of SAAV and DOBV strains. Six PCR-amplicons, two recovered from $A$. agrarius mice and four from $A$. flavicollis mice, were purified and sequenced. Hantaviral M segment sequences of all amplicons were recovered successfully and subjected to genetic analyses. Direct sequence comparison revealed that they form two clearly distinct groups. The first group included five sequences originated from samples \#\#33, 56 (these two sequences were identical and only one, \#56, was taken to further analyses), and \#64 of the May-2003 set and also samples \#\#21 and 109 of the September-2004 set. These sequences showed the highest level of identity (90-98\%) to the corresponding sequences of DOBV strains from Hungary, Slovenia, Greece and Slovakia suggesting that they belong to this hantavirus 
For J.Med.Virol.

187 species. The sequence identity to SAAV strains was substantially lower: $81-84 \%$ :

188 Consequently, the corresponding wild-type (wt) strains were designated as

189 DOBV/Croatia_Nova Gradiška/Af56/2003,

190 DOBV /Croatia_Nova Gradiška / Aa64/2003,

191 DOBV/Croatia_Gratac-MalaKapela/Af21/2004, and

192 DOBV /Croatia_ Delnice-MalaKapela/Af109/2004,

193 or DOBV /Croatia56, DOBV /Croatia64, DOBV/Croatia21, and DOBV /Croatia109

194 for short.

195 The second group was represented by a single sequence recovered from the 196 sample \#12 of the May-2003 set. This sequence was more closely related to SAAV 197 sequences originated from Hungary, Slovakia, Central Russia and Estonia (identity 198 of $90-97 \%$ ) than to DOBV sequences (81-84\%). The corresponding wt strain was 199 designated as SAAV/Croatia_Migalovci/Aa12/2003, or SAAV/Croatia12 for short.

Phylogenetic analysis of the partial $M$ segment sequences confirmed this grouping (Fig. 1). All new Croatian DOBV strains clustered together with other DOBV strains and shared with them a well-supported common ancestor. In contrast, the new Croatian SAAV strain appeared monophyletic with other SAAV strains. Within the SAAV cluster, the Croatian strain shared the most recent common ancestor (TMRCA) with the Hungarian strain and, in turn, these two 206 shared a more anscient common ancestor with the Slovakian strain. Within the

DOBV cluster, two strains (Croatia56 and Croatia64) grouped together, strain 208 Croatia109 shared TMRCA with the prototype DOBV strain from Slovenia while the 209 strain Croatia21 did not group with any particular strain. Interestingly, one of four 
For J.Med.Virol.

210 new DOBV strains, DOBV/Croatia64, was found in A. agrarius field mouse, i.e. not 211 in the traditional host, suggesting a spillover event.

212 Recovery of partial S segment sequences was also attempted on six RT-PCR213 positive samples but only two sequences were obtained: the longer (nt 172 to 1149), 214 for SAAV strain Croatia12 and the shorter (nt 387 to 940), for DOBV strain 215 Croatia56. This made possible to compare the $\mathrm{M}$ segment- and $\mathrm{S}$ segment- based 216 phylogenies and also to compare the newly recovered sequences to the earlier 217 reported DOBV sequences recovered from Croatian HFRS patients: DOBcro100kt, 218 DOBcro126pb, and DOBcro231lm [Markotic et al., 2002]. On the phylogenetic trees 219 calculated for both longer and shorter regions, the new Croatian DOBV and SAAV 220 strains were located within their respective species clusters (on Fig. 2, the tree 221 calculated for the shorter region, nt 387 to 853 , to accommodate the above 222 mentioned Croatian and also the Greek HRFS-originated sequencses, is shown). 223 Thus the topologies of M- and S-trees were similar. The SAAV strain Croatia12 was 224 situated within SAAV cluster, next to the group of SAAV strains from Slovakia. The 225 newly recovered, rodent-originated DOBV strain Croatia56 was placed within 226 DOBV-cluster, together with three sequences described previously from Croatian 227 HFRS patients and also with the sequence of prototype DOBV strain from Slovenia. 228 Five DOBV strains from Greece, together with one strain from Slovakia, form 229 another group. It should be noted that he bootstrap support values for both groups 230 were not convincingly high. Interestingly, one of the Croatian sequences derived 231 from a patient, DOBcro100kt, was particularly close to Slovenian sequence and 232 shared with this prototype sequence a reasonably well supported (69\%) commmon 233 ancestor. Of three DOBV sequences recovered from Greek HFRS cases [Papa et al., 
For J.Med.Virol.

234 1998], two (Greece-PA and Greece -CG) were placed together with high bootstrap

235 support (93\%), while the third sequence, Greece-PR, clustered with two DOBV

236 sequences recovered from A. flavicollis that were trapped in Ano Poroja, northern

237 Greece [Papa et al., 2001]. 
For J.Med.Virol.

\section{DISCUSSION}

The results of this study confirmed the circulation of DOBV in Croatia and also presented the first evidence for the presence of SAAV in local A. agrarius mice. It was clarified that the sequences described previously from Croatian human HFRScases belong to DOBV, not to SAAV. Taken together with the earlier reports on PUUV in Croatia, both in rodents and in association with human HFRS cases [Markotic et al., 2002, Cvetko et al., 2005], the data of (phylo)genetic analyses suggested co-circulation of three pathogenic hantaviruses in this country (the evidence of apathogenic Tula virus was earlier recorded as well [Scharninghausen et al., 2002]). Thus, in that respect, Croatia resembles neighbouring Slovenia and Hungary and also Slovakia where different hantaviruses have been found within a relatively small territory [Avšic-Županc et al., 2000; 2007; Plyusnina et al., 2009; Sibold et al., 1999; 2001]. So far, not a single SAAV genome sequence has been recovered from HFRS patients in these countries suggesting a lower fequency of acute SAAV infection in humans in this part of Europe, in contrast to e.g. Estonia where SAAV-infections are more common that DOBV-infections [Golovljova et al., 2000, 2002, 2007]. Croatian HFRS patients exhibit mostly mild to moderate clinical picture of the disease associated with PUUV, and only a few of them have severe clinical picture associated with DOBV [Markotic et al., 2002]. However, there are some patients with cross-reactive IgG ELISA antibodies to both PUUV and DOBV and usually with moderate to mild clinical picture, which may be possibly linked to SAAV or some other related, but not-yet discovered hantavirus(es) [A. Markotic, unpublished results]. 
For J.Med.Virol.

Recovery of DOBV genome sequences from the tissue sample of A. agrarius mice \#64 trapped in Nova Gradiška is of special interest. So far, all A. agrarius hantaviral sequences belonged to SAAV species (or, according to another suggested classification, to "DOB-Aa", i.e. the subtype of DOBV associated with A. agrarius). All hantavirus-positive rodents analyzed in this study were assigned to A. flavicollis or A. agrarius species using genetic analysis thus leaving no uncertainties. The most likely explanation for finding of DOBV is another rodent species is a spillover of the virus, the phenomenon registered occasionally for other hantaviruses [see, e.g. Klingström et al., 2002] but, before this study, not for DOBV. Most recently, spillover of SAAV from A. agrarius to A. flavicollis mice was desribed in Germany [Schlegel et al., 2009] thus our data on a spillover of DOBV from A. flavicollis to A. agrarius bring a pleasant symmetry to the case.

Another interesting fact is the existence of hantaviral sequences originated from Caucasian wood mice $A$. ponticus and one human HFRS-case from Krasnodar region of Russian Federation [Klempa et al., 2008]. These sequences form a wellsupported group (Fig. 2). The A. ponticus- associated isolate Sochi/Ap shows a respectful 10\% difference from DOBV and SAAV in GnGc protein sequence and also at least 4-fold differences in focus-reduction neutralization titers of some human sera [Klempa et al., 2008]. Should this virus be considered a distinct species?

During the last two decades the data on hantaviruses associated with different species of Apodemus mice in Europe have been accumulating with an increasing speed. Further progress in this field is expected. 
For J.Med.Virol.

Acknowledgements. The work was supported by The Academy of Finland, Sigrid Juselius Foundation (Finland), projects 143-1430115-0103, 068-1430115-2119 and J-29-2007 funded by The Croatian Ministry of Science, Education and Sports, and by EU grant GOCE-2003-010284 EDEN (http://www.eden-fp6project. net/). The paper was catalogued by the EDEN steering committee as EDEN0213.

\section{REFERENCES}

Avšic-Županc T, Petrovec M, Furlan P, Kaps R, Elgh F, Lundkvist Å. 1999. Hemorrhagic fever with renal syndrome in the Dolenjska region of Slovenia-A 10year survey. Clin Infect Dis 28: 860-865.

Avšic-Županc T, Nemirov K, Petrovec M, Trilar T, Poljak M, Vaheri A, Plyusnin A. 2000. Genetic analysis of wild-type Dobrava hantavirus in Slovenia: co-existence of two distinct genetic lineages within the same natural focus. J Gen Virol 81:17471755.

Avšic-Županc T, Petrovec M, Dun D, Plyusnina A, Lundkvist Å, Plyusnin A. 2007. Puumala hantavirus in Slovenia: analyses of $S$ and $M$ segment sequences recovered from patients and rodents. Virus Res 123: 204-210.

Cvetko L, Markotic A, Plyusnina A, Margaletic J, Miletic-Medved M, Turk N, Milas Z, Avšic-Županc T, Plyusnin A. 2005. HFRS and Puumala virus in Croatia during 2002 outbreak. J Med Virol 77:290-294.

Felsenstein 1993. PHYLIP (Phylogeny Inference Package) version 3.5c. Distributed by the author. Department of Genetics, University of Washington, Seattle. 
For J.Med.Virol.

Golovljova I, Vasilenko V, Prukk T, Brus Sjölander K, Plyusnin A, Lundkvist Å. 2000. Puumala and Dobrava hantaviruses causing hemorrhagic fever with renal syndrome in Estonia. Eur J Clin Microbiol Infect Dis 19:968-969.

Golovljova I, Brus Sjölander K, Lindegren G, Vene S, Vasilenko V, Plyusnin `A, Lundkvist Å. 2002. Hantaviruses in Estonia. J Med Virol 68:589-598.

Golovljova I, Vasilenko V, Mittzenkov V, Prukk T, Seppet E, Vene S, Plyusnin A, Lundkvist A. 2007. Characterization of Hemorrhagic Fever with Renal Syndrome caused by hantaviruses, Estonia. Emerg Infect Dis 13:1773-1776.

Heyman P, Vervoort T, Escutenaire S, Degrave E, Konings J, Vandenvelde C, Verhagen R. 2001. Incidence of hantavirus infections in Belgium. Virus Res 77:7180.

Hukic M, Nikolic J, Valjevac A, Šeremet M, Tešic G, Markotic A. 2009. A Serosurvey reveals Bosnia and Herzegovina as a Europe's hotspot in Hantavirus seroprevalence. Epidemiol Infect 2:1-9.

ICTV website: www.ictvonline.org

Jakab F, Sebok J, Ferenczi E, Horváth G, Szucs G. 2007. First detection of Dobrava hantavirus from a patient with severe haemorrhagic fever with renal syndrome by SYBR Green-based real time RT-PCR. Scand J Infect Dis 39:902-906.

Jääskeläinen K, Kaukinen P, Minskaya ES, Plyusnina A, Vapalahti O, Elliott R, Weber F, Vaheri A, Plyusnin, A. 2007. Tula and Puumala hantavirus NSs ORFs are functional and the products inhibit activation of the interferon-beta promoter. J Med Virol.79:1527-1536. 
For J.Med.Virol.

Klempa B, Schütt M, Auste B, Labuda M, Ulrich R, Meisel H, Krüger DH. 2004. First molecular identification of human Dobrava virus infection in Central Europe. J Clin Microbiol 42:1322-1325.

Klempa B, Fichet-Calvet E, Lecompte E, Auste B, Aniskin V, Meisel H, Denys C, Koivogui L, ter Meulen J, Krüger DH. 2006. Hantavirus in African wood mouse, Guinea. Emerg Infect Dis 12: 838-840.

Klempa B, Fichet-Calvet, E, Lecompte E, Auste B, Aniskin V, Meisel, H, Barriere, P, Koivogui L, ter Meulen J, Krüger DH. Novel hantavirus sequences in schrew, Guinea. 2007. Emerg Infect Dis 13:520-522.

Klempa B, Tkachenko EA, Dzagurova TK, Yunicheva YV, Morozov VG, Okulova NM, Slyusareva GP, Smirnov A, Kruger DH. 2008. Hemorrhagic fever with renal syndrome caused by 2 lineages of Dobrava hantavirus, Russia. Emerg Infect Dis 14: 617-625.

Klingström J, Heyman P, Escutenaire S, Sjölander KB, De Jaegere F, Henttonen H, Lundkvist A. 2002. Rodent host specificity of European hantaviruses: evidence of Puumala virus interspecific spillover. J Med Virol 68:581-588.

Kuzman I, Puljiz I, Turcinov D, Markotic A, Turkovic B, Aleraj B, Andric Z, Petkovic D, Tutek V, Herendic B, Iskra M, Pandak N, Misetic Z, Peric L, Jelaska D, Majetic-Sekovanic M, Ledina D, Misic-Majerus L, Radonic R. 2003. [The biggest epidemic of hemorrhagic fever with renal syndrome in Croatia (in Croatian, Abstract - English)]. Acta Med Croatica 57:337-346.

Lundkvist Å, Vasilenko V, Golovljova I, Plyusnin A, Vaheri, A. 1998. Human Dobrava hantavirus infections in Estonia. Lancet 352:369. 
For J.Med.Virol.

Markotic A, LeDuc JW, Hlaca D, Rabatic S, Šarcevic A, Dašic G, Gagro A, Kuzman I, Barac V, Avšic-Županc T, Beus I, Dekaris D 1996. Hantaviruses are a likely threat to NATO forces in Bosnia and Herzegovina and Croatia. Nature Med 2:269270 .

Markotic A, Nichol ST, Kuzman I, Sanchez AJ, Ksiazek TG, Gagro A, Rabatic S, Zgorelec R, Avšic-Županc T, Beus I, Dekaris D.2002. Characteristics of Puumala and Dobrava Infections in Croatia. J Med Virol; 66:542-551.

Mustonen J, Brummer-Korvenkontio M, Hedman K, Pqasternak A, Pietilä K, Vaheri A. 1994. Nephropathia epidemica in Finland. A retrospective study of 126 cases. Scand J Infect Dis 26:7-13.

Nemirov K, Vapalahti O, Lundkvist Å, Vasilenko V, Golovljova I, Plyusnina A, Niemimaa J, Laakkonen J, Henttonen H, Vaheri A, Plyusnin A. 1999. Isolation and characterization of Dobrava hantavirus carried by the striped field mouse (Apodemus agrarius) in Estonia. J Gen Virol 80:371-379.

Nemirov K, Henttonen H, Vaheri A, Plyusnin A. 2002. Phylogenetic evidence for host switching in the evolution of hantaviruses carried by Apodemus mice. Virus Res 90: 207-215, 2002. (Corrigendum: Virus Res 92:125-126, 2003).

Nichol ST, Beaty BJ, Elliott RM, Goldbach R, Plyusnin A, Schmaljohn CS, Tesh, RB. 2005. Bunyaviridae. In Virus taxonomy. VIIIth report of the International Committee on Taxonomy of Viruses (Fauquet CM, Mayo MA, Maniloff J, Desselberger U, Ball LA - Eds), pp. 695-716. Elsevier Academic Press, Amsterdam.

Papa A, Johnson AM, Stockton PC, Bowen MD, Spiropoulou CF, Alexiou-Daniel S, Ksiazek TG, Nichol ST, Antoniadis A. 1998. Retrospective serologic and genetic study of the distribution of hantaviruses in Greece. J Med Virol 55: 321-327. 
For J.Med.Virol.

406

407

408

409

410

411

412

413

414

415

416

417

418

419

420

421

422

423

424

425

426

427

428

429

430

431

432

433

434

435

436

50

51

52

53

54

55

56

57

58

59

60

Papa A, Nemirov K, Henttonen H, Antoniandis A, Vaheri A, Plyusnin, A, Vapalahti O. 2001. Isolation of Dobrava virus from A. flavicollis in Greece. J Clin

Microbiol 39:2291-2293.

Plyusnin A, Cheng Y, Vapalahti O, Pejcoch M, Unar J, Jelinkova Z, Lehväslaiho H, Lundkvist ̊̊, Vaheri, A. 1995. Genetic variation in Tula hantaviruses:; sequence analysis of the $\mathrm{S}$ and $\mathrm{M}$ segments of strains from Central Europe. Virus Res 39: 237-250.

Plyusnin A, Vapalahti O, Vasilenko V, Henttonen H, Vaheri A. 1997. Dobrava hantavirus in Estonia: does the virus exist throughout Europe? Lancet 349:13691370.

Plyusnin A, Nemirov K, Apekina N, Plyusnina A, Lundkvist ̊̊, Vaheri A. 1999. Dobrava hantavirus in Russia. Lancet 353:207.

Plyusnina A, Ferenczi E, Racz GR, Nemirov K, Lundkvist Å, Vaheri A, Vapalahti O, Plyusnin A. 2009. Co-circulation of three pathogenic hantaviruses: Puumala, Dobrava and Saaremaa hantaviruses in Hungary. J Med Virol 81:2045-2052.

Schmaljohn CS, Hjelle B. 1997. Hantaviruses: a global disease problem. Emerg Infect Dis 3:95-104.

Settergren B, Juto P, Trollfors B, wadell G, Norrby SR. 1989. Clinical characteristics of nephropathia epidemica in Sweden: prospective study of 74 cases. Rev Inf Dis 11:921-927.

Scharninghausen JJ, Pfeffer M, Meyer H, Davis DS, Honeycutt RL, Faulde M. 2002. Genetic evidence for tula virus in Microtus arvalis and Microtus agrestis populations in Croatia. Vector Borne Zoonotic Dis 2:19-27. 
For J.Med.Virol.

Schlegel M, Klempa B, Auste B, Bemmann M, Schmidt-Chanasit J, Büchner T, Groschup MH, Meier M, Balkema-Buschmann A, Zoller H, Krüger DH, Ulrich RG. 2009. Dobrava-Belgrade virus spillover infections, Germany. Emerg Infect Dis 15:2017-2020.

Sibold C, Meisel H, Lundkvist Å, Schulz A, Cifire F, Ulrich R, Kozuch O, Labuda M, Krüger DH. 1999. Short report: simultaneous occurrence of Dobrava, Puumala, and Tula hantaviruses in Slovakia. Am J Trop Med Hyg 61:409-11.

Sibold C, Ulrich R, Labuda M, Lundkvist $\AA$, Martens H, Schutt M, Gerke P, Leitmeyer K, Meisel H, Krüger DH. 2001. Dobrava hantavirus causes hemorrhagic fever with renal syndrome in central Europe and is carried by two different Apodemus mice species. J Med Virol 63:158-167.

Tkachenko E, Dekonenko A, Ivanov A, Dzagurova T, Ivanov L, Slonova R, Nirgaleeva R, Stepanenko A, Ivanidze E, Zagidullin I. 1999. Hemorrhagic fever with renal syndrome and hantaviruses in Russia. In: Dodet B, Saluzzo J - Eds. Emergence and control of rodent-borne viral diseases. Amsterdam: Elsevier, p.6372.

Vapalahti O, Mustonen J, Lundkvist Å, Henttonen H, Plyusnin A, Vaheri A. 2003. Hantavirus infections in Europe (Review). Lancet Infect Dis 3:653-661. 
For J.Med.Virol.

$459 \quad$ Legends to figures

460

Fig. 1. Phylogenetic tree of hantaviruses based on partial M segment sequences (nt 462 1749-2019). Abbreviations: SNV, Sin Nombre virus, strain NM H10; NYV, New York 463 virus, strain H-NY1; ELMCV, El Moro Canyon virus, strain RM-97; LANV, Laguna 464 Negra virus, strain 510B; BAYV, Bayou virus, strain Louisiana; BCCV, Black Creek 465 Canal virus; SEOV; seoul virus, strain 80-39; THAIV, Thailand virus, strain 741; 466 HTNV, Hantaan virus, strain 76-118; SAAV, Saaremaa virus; DOBV, Dobrava467 Belgrade virus; PHV, Prospect Hill virus, strain PH-1; TULV, Tula virus, strain 468 Moravia02v; PUUV, Puumala virus, strain Sotkamo; TOPV, Topografov virus, strain 469 Ls136v; KHAV, Khabarovsk virus, strain MF-43.

Fig. 2. Phylogenetic tree of Dobrava, Saaremaa and related hantaviruses based on 472 partial S segment sequences (nt 387-853). ASV, Amur-Soochong virus, strain 473 Soochong1. For other abbreviations, see Fig. 1. 